\title{
The influence of wind-induced compression failures on the mechanical properties of spruce structural timber
}

\author{
M. Arnold • R. Steiger
}

Received: 8 June 2005 / Accepted: 18 November 2005 / Published online: 5 July 2006

(C) RILEM 2006

\begin{abstract}
Compression failures (CF) are defects in the wood structure in the form of buckled fibres. They are a well-known 'natural' phenomenon in softwood trees exposed to frequent or strong winds, but their influence on the utilisation of timber is still debated. While a reduction of the mechanical properties in bending and tension at the fibre level and in small clear specimens is generally acknowledged, the effect is less obvious with structural timber in the presence of other defects such as knots or grain deviations. In the presented case study a statistically significant reduction of the moduli of rupture and elasticity in bending is observed in a sample of 563 squared timber beams, but the characteristic values of the mechanical properties still exceed the limits for the strength classes of visually graded structural timber (according to the Swiss standard SIA 265). Nevertheless, because of the potential safety risk by the more brittle fracture behaviour, it is recommended to exclude timber with detected CF from use in load bearing structures stressed in tension or bending.
\end{abstract}

Résumé - Parlant de fractures de compression (CF) on y comprend des détériorations de la structure $d u$ bois en forme des fibres infléchis. Ce phénomène est très connu pour les arbres résineux qui sont exposés au vent

M. Arnold $(\varangle) \cdot$ R. Steiger

Empa, Swiss Federal Laboratories for Materials Testing and Research, Wood Laboratory, Überlandstrasse 129, CH-8600 Dübendorf, Switzerland

e-mail: martin.arnold@empa.ch fréquent ou fort, mais son influence sur l'utilisation $d u$ bois est encore discutée. Tandis que une perte de résistance et rigidité en cas de flexion et de traction est généralement reconnaît sur le niveau des fibres et aussi en cas des éprouvettes de petites dimensions sans défauts, l'influence sur les propriétés mécaniques des éléments porteuses avec des plus grandes dimensions et avec des næuds ou des déviations des fibres est moins évident. L'étude-ci confirme une réduction significative de la résistance et de la rigidité en flexion pour une échantillon de 563 poutres équarris en bois massif, tandis que pour les classes de résistance du bois trié selon des critères visuelles (d'après la norme Suisse SIA 265) les valeurs caractéristiques sont surpassé. Il est recommandé tout de même de ne pas utiliser du bois avec CF discerné pour des éléments structuraux porteuses sollicité en traction ou flexion à cause de son comportement plus fragile et plus sec en cas de rupture.

Keywords Compression failures · Storm damage · Structural timber · Grading · Wood mechanics

\section{Introduction}

Compression failures (CF) are defects in the wood structure in the form of buckled cell walls of the wood fibres. They may be wind-induced in the standing trees, if the stems are bent so much by frequent or strong winds that the proportionality limit of the wood in axial compression is locally exceeded on the inward 


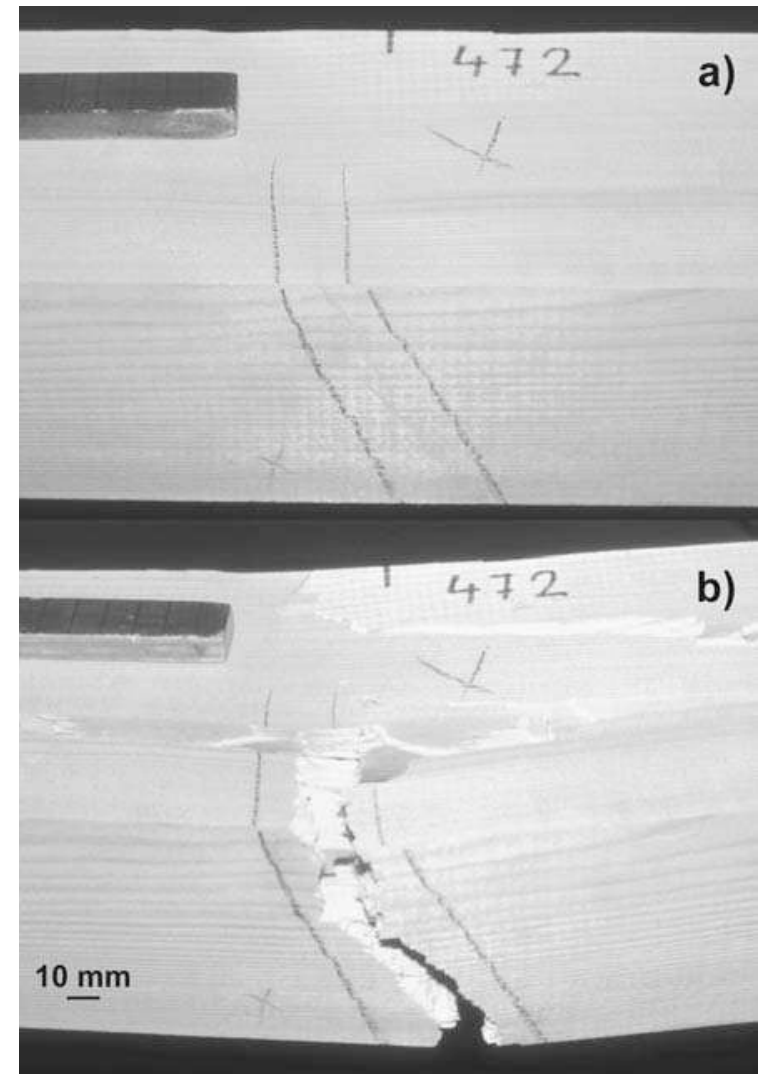

Fig. 1 A wind-induced compression failure in a squared timber beam before (a) and after (b) a destructive bending test. Initially the CF was barely visible on the planed surface, but the fracture was initiated directly in the previously marked $\mathrm{CF}$ and was extremely brittle and short-fibred

(leeward) side of the bow. The distorted fibres of CF remain as weak points in the wood and can lead to brittle fractures in processed timber already at a relatively low stress in bending or tension (Fig. 1). Therefore CF are regarded as unwanted structural defects.

$\mathrm{CF}$ are a well-known 'natural' phenomenon and are observed quite frequently in some of our lower density native softwoods such as spruce (Picea abies) [1-5]. Particularly after heavy storm damages in the forests, questions regarding their influence on the utilisation of timber from the salvaged trees arise anew.

$\mathrm{CF}$ are complex three-dimensional geometric structures with more or less fuzzy boundaries and appear in a broad range of intensities. Their size can range from minute deformations in the cell wall to wide bands of several millimetres in width, which can affect more than half of the stem's cross-section. Because of their diverse appearance various terms are in use [6-7]. Re- garding processing and grading it is important to note that $\mathrm{CF}$ are usually difficult to detect, particularly in rough sawn timber.

The consequences of CF on the utilisation of affected timber and particularly on its mechanical properties are still debated. While a reduction of the mechanical properties (mainly in bending and tension) at the fibre level [8] and in small clear wood specimens is generally acknowledged [5, 9], the effect is less clear with structural timber, where the effect of CF may be confounded by the presence of other defects such as knots or grain deviations [10-11]. Particularly regarding the effect of $\mathrm{CF}$ in structural timber only few comprehensive studies have been published so far.

However, because of their potential safety risk, many grading standards explicitly [12] or implicitly exclude CF from timber elements in load bearing structures. CF therefore can impose serious restrictions on the utilization of wind-damaged timber and require additional efforts regarding grading and quality control. Historical example: CF used to be particularly feared of in the production of wooden ladder rails or wooden parts for airplanes (e.g. wings).

The presented work is part of an extensive research project in Switzerland started after the extraordinarily violent winter storm 'Lothar' in December 1999, aiming at collecting more information regarding the extent and location, the causes, the detection, and the consequences of wind-induced CF [13].

The objective of this paper is to present new extensive data concerning the effect of wind-induced CF on the mechanical properties of structural timber stressed in bending and to draw conclusions regarding the consideration of $\mathrm{CF}$ in grading rules.

\section{Materials and methods}

\subsection{Sample material}

The investigations were set up in the form of a case study. 30 spruce (Picea abies) trees were harvested in July 2000 from a mature, even-aged, heavily stormdamaged forest stand near Zurich, Switzerland. The selected trees were fully-grown and about 120 years old at the time of the storm. The diameter at breast height ranged from $39 \mathrm{~cm}$ to $72 \mathrm{~cm}$, the tree height was between $35 \mathrm{~m}$ and $43 \mathrm{~m}$. 


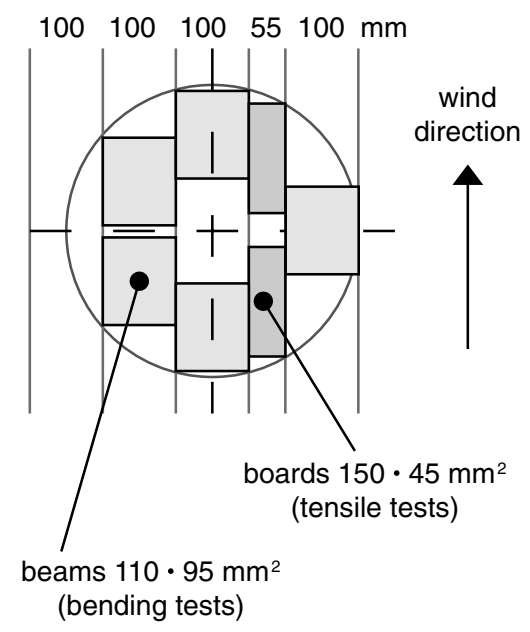

Fig. 2 Sawing pattern and arrangement of test pieces

3-5 logs of $5 \mathrm{~m}$ length were cut from each tree, graded and visually inspected for CF after partial debarking. $133 \operatorname{logs}$ with a total volume of about $90 \mathrm{~m}^{3}$ were processed. All logs were then sawn into boards of $100 \mathrm{~mm}$ or $55 \mathrm{~mm}$ thickness, according to a systematic sawing pattern adjusted to the previously marked main wind direction of the storm (Fig. 2). This direction was corresponding mostly to the largest stem eccentricity, which again matched the usually westerly wind direction in this stand.

The sawn boards were subsequently cut into various test pieces (full-size structural timber as well as small clear specimens) for the assessment of various mechanical wood properties in bending, tension and compression. However, this paper is focusing only on the bending tests of structural timber. Results of the tests with small clear specimens from the same sample material have been published already earlier [9].

Each test piece was identified by its origin regarding tree, $\log$ and position in the stem cross-section. Depending on the diameter of the log, the sawing process resulted in a different number of timber pieces (1 to 11 pieces per log) with varying growth ring orientations. Since all harvested logs of the trees were converted into test pieces, a wide range of wood quality was included in the sample. All sawn pieces were kiln-dried to a wood moisture content of $15 \%$ and planed to their final dimension. A sample of 563 squared timber beams $\left(2200 \cdot 110 \cdot 95 \mathrm{~mm}^{3}\right)$ was finally available for testing.

\subsection{Grading and detection of $\mathrm{CF}$}

Each beam was visually graded into 4 strength classes (I, II, III, ungraded) according to the supplementary specifications of the Swiss standard for the design of timber structures SIA 265/1 [12]. These visual grades are linked to the strength classes C24 (I + II) and C20 (III) according to the European standard EN 338 [14]. Due to practical reasons, visual grade I is currently assigned to C24 instead of the theoretically possible strength class C27. Deviating from the grading rules, beams with detected CF were not considered in the classification and therefore not excluded. Additionally, the wood density and the axial ultrasonic speed were measured. However, these additional parameters were not used to derive the strength classes, but recorded together with the main visual quality characteristics of each beam to be used later in the data analysis (Table 1).

Prior to testing all beams were carefully inspected for $\mathrm{CF}$ and the detected $\mathrm{CF}$ were marked (Fig. 1). A reliable detection of $\mathrm{CF}$ is difficult and depends on the light conditions, the angle of observation, the surface structure, and the experience of the observer. All macroscopically visible $\mathrm{CF}$ on the longitudinal faces of the beams were assessed. Because the inspection was made on planed surfaces, even rather fine $\mathrm{CF}$ could be detected. For each beam the 'intensity' of CF was recorded as the total number of identified $\mathrm{CF}$ and the 'size' of the largest CF (Table 2). The 'size' was assessed by a system simplifying the complex geometric structure of the CF to a one level defect plane, defined by its maximum axial 'width' (CFMAX, Table 3 ) and the visible length on the circumference of the beam (CFLEN, Table 2). This procedure resulted in 2 sub-samples of beams without and with CF (CFIND, Table 2).

\subsection{Bending tests}

4-point static bending tests were conducted according to EN 408 [15] (Fig. 3). The speed of the loading head was set to $0.2 \mathrm{~mm} / \mathrm{s}$, resulting in an average time to failure of $210 \mathrm{~s}$. Time to failure was shorter than $180 \mathrm{~s}$ with 238 beams due to particular brittle fracture behaviour with a small deformation at maximum load (see 3.4). Deformation was measured on both side faces at the neutral axis over the total span as well as within the central gauge length and averaged over the two faces. The beams were cut so that the critical section with the expected failure location (e.g. knots, 
Table 1 Wood quality and grading parameters recorded during grading procedures

\begin{tabular}{|c|c|c|c|}
\hline Code & Parameter & Unit & Details \\
\hline DENS & Wood density & {$\left[\mathrm{kg} / \mathrm{m}^{3}\right]$} & $\begin{array}{l}\text { Calculated from mass and volume of whole beam } \\
\text { at } 15 \% \mathrm{MC}\end{array}$ \\
\hline USMIN & Axial ultrasonic speed & {$[\mathrm{m} / \mathrm{s}]$} & $\begin{array}{l}\text { Minimum value of } 2 \text { measurements (device } \\
\text { 'Sylvatest') }\end{array}$ \\
\hline KMAX & Diameter of largest knot & {$[\mathrm{mm}]$} & $\begin{array}{l}\text { Measured perpendicular to axis of beam; only } \\
\text { knots between loading heads (inner third of } \\
\text { span) }\end{array}$ \\
\hline KCLU & Size of largest knot cluster & {$[\mathrm{mm}]$} & $\begin{array}{l}\text { Maximum sum of knot diameters ( } 2 \text { or more } \\
\text { knots) within } 150 \mathrm{~mm} \text { length }\end{array}$ \\
\hline $\mathrm{CW}$ & Compression wood & {$[\%]$} & Affected cross-section $(0,5,10,20,30, . .100 \%)$ \\
\hline FUNG & $\begin{array}{l}\text { Discouloring fungal attack } \\
\text { in sapwood }\end{array}$ & {$[\%]$} & $\begin{array}{l}\text { Affected cross-section by blue stain or red stripe } \\
\quad(0,5,10,20,30, . .100 \%)\end{array}$ \\
\hline SCSIA & strength class & & $\begin{array}{l}\text { I, II, III, ungraded (i.e. unfit for structural timber); } \\
\text { by visual grading according to SIA } 265 / 1 \text { [12] }\end{array}$ \\
\hline
\end{tabular}

Table 2 Assessment parameters of $\mathrm{CF}$

\begin{tabular}{llll}
\hline Code & Parameter & Unit & Details \\
\hline CFIND & $\begin{array}{c}\text { Binary indicator variable } \\
\text { for presence of CF }\end{array}$ & 0 = without CF, 1 = with CF \\
NCF & $\begin{array}{c}\text { Number of (single) } \\
\text { detected CF }\end{array}$ & \\
CFMAX & $\begin{array}{l}\text { Axial 'width' of largest } \\
\text { CF }\end{array}$ & {$[\mathrm{mm}]$} & see Table 3 \\
CFLEN & Circumferential length of & {$[\mathrm{mm}]$} & $\begin{array}{c}\text { Visible length on tension edge } \\
\text { and side faces }\end{array}$ \\
\hline
\end{tabular}

Table 3 Definition of discrete rating scale for visual assessment of axial 'width' of CF (CFMAX)

\begin{tabular}{|c|c|c|}
\hline Max. (axial) width of CF & Definition & Remarks \\
\hline $0.1 \mathrm{~mm}$ & $\begin{array}{l}\text { Very fine CF; just visible with } \\
\text { normal corrected vision }\end{array}$ & $\begin{array}{l}\text { Can be missed under insufficient } \\
\text { illumination }\end{array}$ \\
\hline $0.5 \mathrm{~mm}$ & $\begin{array}{l}\text { Fine, but perceptible CF; clearly } \\
\text { visible with normal corrected } \\
\text { vision }\end{array}$ & $\begin{array}{l}\text { Will normally be detected by } \\
\text { careful visual inspection of } \\
\text { planed surfaces }\end{array}$ \\
\hline $1.0 \mathrm{~mm}$ & Distinct CF; clearly visible & \\
\hline$>1 \mathrm{~mm}(1.5,2.0, \ldots)$ & Large and significant $\mathrm{CF}$ & Classified in intervals of $0.5 \mathrm{~mm}$ \\
\hline
\end{tabular}

CF) was positioned between the inner loading points. To reproduce the original loading situation in the tree, the beams were loaded towards the nearer peripheral stem side (i.e. beams from the leeward side of the stem were loaded in the wind-direction and vice-versa). With this procedure, present $\mathrm{CF}$ were positioned in the majority on the tension edge and thus the beams were loaded in their most critical orientation. Resulting parameters were modulus of rupture (MOR), modulus of elasticity (MOE) and total deformation at maximum load (DMAX, Table 4).

\subsection{Data analysis}

The test results were analysed with two different approaches focusing on the statistical significance and the practical relevance of the effect of CF on the mechanical properties. Further topics included the characterisation 
Table 4 Result parameters of bending test

\begin{tabular}{llll}
\hline Code & Parameter & Unit & Details \\
\hline MOR & Modulus of rupture & {$\left[\mathrm{N} / \mathrm{mm}^{2}\right]$} & $\begin{array}{l}\text { Calculated for nominal cross section of } \\
110.95 \mathrm{~mm}(\mathrm{~h} \cdot \mathrm{b})\end{array}$ \\
MOE & Modulus of elasticity & {$\left[\mathrm{N} / \mathrm{mm}^{2}\right]$} & \\
DMAX & Total deformation at maximum load & {$[\mathrm{mm}]$} & $\begin{array}{c}\text { Measured at neutral axis over 1980 } \\
\text { mm span }\end{array}$ \\
& & & \\
\hline
\end{tabular}

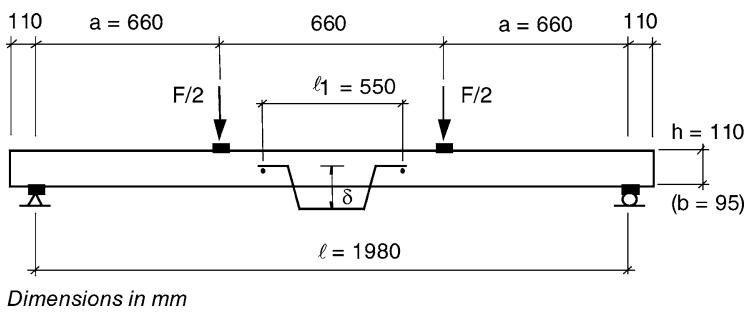

Fig. 3 Configuration of 4-point bending test according to EN 408

of the sample material, the effect of the 'size' of the CF and the fracture behaviour.

The statistical significance of the effect of $\mathrm{CF}$ on the mechanical properties was assessed with a multiple regression approach. A direct comparison of sub-sample means of beams without and with $\mathrm{CF}$ may be confounded due to differences in other quality parameters (e.g. density, knots, compression wood). The multiple regression methodology allows a simultaneous exploration of the effects of several 'independent' quality parameters on the 'dependent' mechanical properties, thus leading to 'adjusted' estimates of the single influencing factors.

The same main factor model without interaction terms was used for both dependent variables MOR and MOE as defined in formulas 1 and 2, thus allowing a comparison of the respective influence of the same factors in both models:

$$
\begin{aligned}
\mathrm{MOR}= & a_{0}+a_{1} \cdot \mathrm{DENS}+a_{2} \cdot \mathrm{USMIN}+a_{3} . \\
& \mathrm{KMAX}+a_{4} \cdot \mathrm{KCLU}+a_{5} \cdot \mathrm{CW}+a_{6} . \\
& \mathrm{FUNG}+a_{7} \cdot \mathrm{CFIND}+\varepsilon_{1}
\end{aligned}
$$

$\mathrm{MOE}=b_{0}+b_{1} \cdot \mathrm{DENS}+b_{2} \cdot \mathrm{USMIN}+b_{3}$.

$$
\begin{aligned}
& \mathrm{KMAX}+b_{4} \cdot \mathrm{KCLU}+b_{5} \cdot \mathrm{CW}+b_{6} . \\
& \mathrm{FUNG}+b_{7} \cdot \mathrm{CFIND}+\varepsilon_{2}
\end{aligned}
$$

where $a_{0}-a_{7}$ and $b_{0}-b_{7}$ are regression coefficients and $\varepsilon_{1}$ and $\varepsilon_{2}$ are error terms in the models 1 and 2 respectively. The used abbreviation codes for the regression variables are listed in Tables 1-4 and will be used throughout the presentation of the results.

The effect of CF was included as a binary variable, indicating only the absence (0) or presence (1) of CF within a beam (CFIND, Table 2). The estimated effect for CFIND is the nominal contribution of the CF on the tested dependent mechanical property. Interaction terms were not included in the models because they were not significant at the $5 \%$ level in most cases. All 563 tested beams have been included in this analysis.

The practical relevance of CF regarding the mechanical properties was assessed by comparing the characteristic values of the visually strength graded beams (including both beams without and with $\mathrm{CF}$ ) as determined according to prEN 384 [16] with the limits of the given strength classes according to SIA 265 [17] and EN 338 [14]. 'Ungraded' beams were not included in this analysis.

\section{Results and discussion}

\subsection{Properties of sample material}

CF were found in 29 of the 30 investigated trees, which points to a rather high incidence of $\mathrm{CF}$ in the sample material. $\mathrm{CF}$ were located almost exclusively on the leeward side of the stems, indicating wind-induced rather than fall-induced CF [13]. In fact 200 (36\%) of the 563 tested beams contained CF in various 'intensities' (Table 5). The proportion of beams containing CF increased in the lower strength classes. Only very few beams (24) were visually graded as strength class I, 145 and 197 beams were graded as strength class II and III respectively and a rather high number of beams (197) were graded unfit for structural timber ('ungraded'). Big knots and severe compression wood (CW > 20\% 
Table 5 Number of tested beams grouped by presence of CF (CFIND) and strength class (SCSIA)

\begin{tabular}{llllll}
\hline & \multicolumn{4}{c}{ Strength class (SCSIA) } \\
\cline { 2 - 5 } Presence of CF (CFIND) & I/C24 & II/C24 & III/C20 & Ungraded & Total \\
\hline 0 & $23^{\mathrm{b}}(4.1 \%)$ & $114(20.3 \%)$ & $120(21.3 \%)$ & $106(18.8 \%)$ & $363(64.5 \%)$ \\
1 & $1(0.2 \%)$ & $31(5.5 \%)$ & $77(13.7 \%)$ & $91(16.2 \%)$ & $200(35.5 \%)$ \\
Total & $24(4.3 \%)$ & $145(25.8 \%)$ & $197(35.0 \%)$ & $197(35.0 \%)$ & $563(100 \%)$ \\
\hline
\end{tabular}

Note: a Accord. to SIA 265/1 [12] visual grade I is assigned to C24 (see 2.2)

${ }^{\mathrm{b}}$ Numbers indicate absolute and relative (in brackets) frequencies

Table 6 Sample statistics for selected wood quality parameters grouped by presence of $\mathrm{CF}$ (CFIND)

\begin{tabular}{cllllrr}
\hline & CFIND & $n^{\mathrm{a}}$ & Mean $^{\mathrm{a}}$ & Std $^{\mathrm{a}}$ & Min $^{\mathrm{a}}$ & Max $^{\mathrm{a}}$ \\
\hline DENS & 0 & 363 & 472 & 34 & 367 & 570 \\
{$\left[\mathrm{~kg} / \mathrm{m}^{3}\right]$} & 1 & 200 & 506 & 38 & 424 & 602 \\
USMIN & 0 & 363 & 5907 & 240 & 4834 & 6295 \\
{$[\mathrm{~m} / \mathrm{s}]$} & 1 & 200 & 5850 & 243 & 5123 & 6284 \\
$\mathrm{KMAX}$ & 0 & 363 & 22.4 & 11.3 & 0 & 55 \\
{$[\mathrm{~mm}]$} & 1 & 200 & 23.5 & 10.6 & 0 & 50 \\
KCLU & 0 & 363 & 20.7 & 22.9 & 0 & 90 \\
{$[\mathrm{~mm}]$} & 1 & 200 & 17.5 & 21.3 & 0 & 90 \\
$\mathrm{CW}$ & 0 & 363 & 9.9 & 15.0 & 0 & 70 \\
{$[\%]$} & 1 & 200 & 21.6 & 14.1 & 0 & 80 \\
FUNG & 0 & 363 & 8.7 & 8.9 & 0 & 40 \\
{$[\%]$} & 1 & 200 & 9.6 & 9.0 & 0 & 40 \\
\hline
\end{tabular}

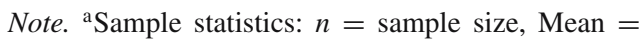
arithmetic mean, $\mathrm{Std}=$ standard deviation, $\mathrm{Min}=\min$ imum value, $\mathrm{Max}=$ maximum value

in 127 of the beams) were the most frequent reasons for downgrading.

Sample statistics for some selected wood quality and grading parameters are presented in Table 6 . The wood density is typical for native spruce timber in Switzerland [18], but somewhat higher than in other recent studies $[10,11]$. The sample material covers a wide quality range from beams free of knots to beams from the upper logs with some rather large knots (diameter up to $55 \mathrm{~mm}$ ). Except for wood density and the amount of compression wood, the wood quality parameters were very similar in both sub-samples of beams without and with CF.

Beams with CF contained between 1 and 12 individual $\mathrm{CF}$ (NCF, Table 7). The average axial 'width' of the largest CF (CFMAX) was $0.7 \mathrm{~mm}$, starting with a minimum of $0.1 \mathrm{~mm}$ as given in the rating scale in Table 3 to a maximum of $3 \mathrm{~mm}$. 75 (38\%) of the beams with $\mathrm{CF}$ contained rather large $\mathrm{CF}$ (CFMAX $\geq$
Table 7 Sample statistics for $\mathrm{CF}$ 'intensities' in beams with $\mathrm{CF}(\mathrm{CFIND}=1)$

\begin{tabular}{lllllll}
\hline & CFIND & $n^{\mathrm{a}}$ & $\mathrm{Mean}^{\mathrm{a}}$ & $\mathrm{Std}^{\mathrm{a}}$ & $\operatorname{Min}^{\mathrm{a}}$ & $\mathrm{Max}^{\mathrm{a}}$ \\
\hline NCF [pieces] & 1 & 200 & 3.8 & 2.5 & 1 & 12 \\
CFMAX [mm] & 1 & 200 & 0.7 & 0.5 & 0.1 & 3.0 \\
CFLEN [mm] & 1 & 200 & 128 & 77 & 0 & 315 \\
\hline
\end{tabular}

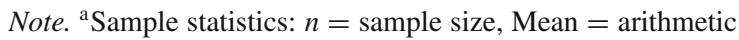
mean, $\mathrm{Std}=$ standard deviation, Min = minimum value, Max $=$ maximum value

1), while on the remaining 125 beams the largest $\mathrm{CF}$ was only detectable upon a careful visual inspection of the planed surfaces. The circumferential length on the tension edge and on the side faces of the largest CF (CFLEN) was on average $128 \mathrm{~mm}$, with a range from 0 (CF on compression face only) to the maximum possible length of $315 \mathrm{~mm}$ (CF over full length of circumference).

For the interpretation of the results it must be noted that the sample material consisted of timber from a heavily storm-damaged stand. As a consequence of the prevailing westerly wind exposure of the forest stand, compression wood was frequent and concentrated on the leeward sides of the stems, and often related to $\mathrm{CF}$ induced during earlier storms. Compared to earlier studies with structural timber $[10,11]$, we have tested a notably larger number of specimens with CF and with a higher 'intensity' of CF.

\subsection{Effect of $\mathrm{CF}$ on mechanical properties}

Selected sample statistics for modulus of rupture (MOR), modulus of elasticity (MOE) and total deformation at maximum load (DMAX) are given in Table 8 . As already seen with the wood density, MOR and MOE are in the usual range observed for spruce timber in Switzerland [18], but somewhat higher than 
Table 8 Sample statistics for bending test results grouped by presence of CF (CFIND)

\begin{tabular}{cllllll}
\hline & CFIND & $n^{\mathrm{a}}$ & Mean $^{\mathrm{a}}$ & Std $^{\mathrm{a}}$ & Min $^{\mathrm{a}}$ & Max $^{\mathrm{a}}$ \\
\hline MOR & 0 & 363 & 53.0 & 9.9 & 23.1 & 76.3 \\
{$\left[\mathrm{~N} / \mathrm{mm}^{2}\right]$} & 1 & 200 & 45.8 & 11.4 & 12.2 & 71.6 \\
$\mathrm{MOE}$ & 0 & 363 & 12451 & 2149 & 4550 & 16877 \\
{$\left[\mathrm{~N} / \mathrm{mm}^{2}\right]$} & 1 & 200 & 12200 & 1971 & 6863 & 18041 \\
DMAX & 0 & 363 & 55.7 & 17.6 & 19.9 & 106.4 \\
{$[\mathrm{~mm}]$} & 1 & 200 & 39.3 & 14.7 & 12.4 & 81.5 \\
\hline
\end{tabular}

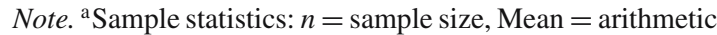
mean, $\mathrm{Std}=$ standard deviation, Min $=$ minimum value, Max $=$ maximum value

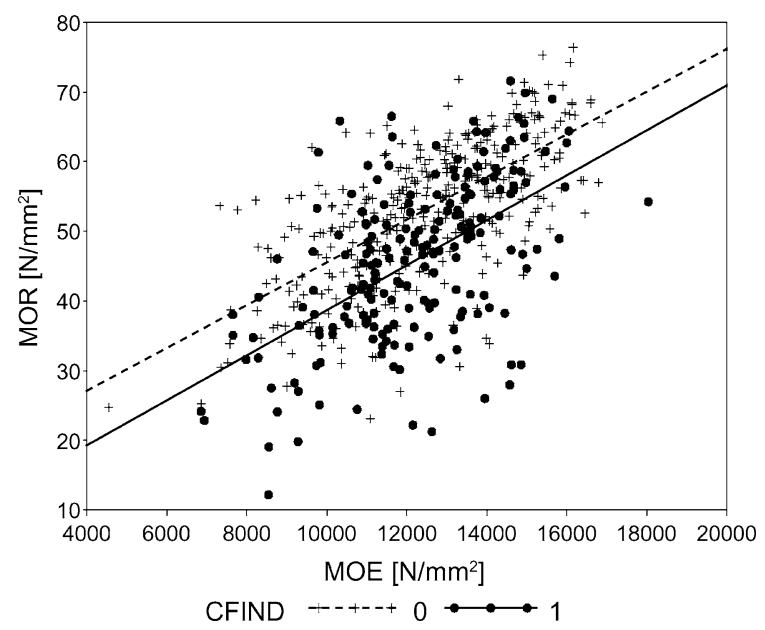

Fig. 4 Effect of the presence of CF (CFIND) on the relationship between modulus of rupture (MOR) and modulus of elasticity (MOE). The dotted and the solid lines indicate the linear regression lines for the two groups of beams without and with $\mathrm{CF}$ respectively

in other recent studies on the effects of CF [10, 11]. Variability (standard deviation) within the sub-samples without and with CF is very similar. The mean values of MOR and DMAX are distinctly lower in beams with $\mathrm{CF}, \mathrm{MOE}$ differs only slightly. The effect of CF on the relationship between MOR and MOE is further illustrated in Fig. 4, confirming a clear reducing effect on MOR, but only a small effect on MOE.

The results of the multiple regression analysis corresponding to model formulas 1 and 2 are listed in Table 9. Both models show a high overall statistical significance with a coefficient of determination ( $R$-Square) of 0.45 for MOR and 0.69 for MOE. This agrees well with the usually observed better correlation between wood quality parameters and MOE than with MOR. Except for compression wood (CW) in the MOR model, all included factors are significant at the 5\% error level. The diameter of the largest knot (KMAX) and the presence of CF (CFIND) are the most important factors in the MOR model, while wood density (DENS) and axial ultrasonic speed (USMIN) are particularly dominant in the MOE model.

The highly significant regression coefficient of the indicator variable for the presence of CF (CFIND) in both models indicates a statistically supported negative effect of the CF on both MOR and MOE. Because of the binary scale of the indicator variable CFIND, the parameter estimates give directly the nominal average effect of the presence of CF. For MOR this means that the presence of $\mathrm{CF}$ reduces the bending strength 'on average' by $8.1 \mathrm{~N} / \mathrm{mm}^{2}$ (with $95 \%$-confidence limits between 9.7 and $6.5 \mathrm{~N} / \mathrm{mm}^{2}$ ). This estimate closely matches the difference of the mean values in Table 8 and the distance of the regression lines in Fig. 4. Related to the mean value of the beams without $\mathrm{CF}$ this corresponds to an average reduction of MOR by $15 \%$. The estimate for the effect on MOE is $-526 \mathrm{~N} / \mathrm{mm}^{2}$, which is a somewhat higher reduction than the nominal difference of the mean values (Table 8), but is still only a $4 \%$ reduction related to the mean value of the beams without CF. However, even this small reduction is statistically significant.

The above presented results are based on the whole sample of 563 beams, covering a wide range of wood quality and strength grades. However, regression analysis stratified by strength classes and stem sections leads to very similar results regarding the effect of $\mathrm{CF}$. This is interpreted as a general confirmation of the validity of the used overall model. Only a slightly increasing effect of CF can be observed in the higher strength grades, which is most likely due to the decreasing amount of other structural defects.

The identified more dominant effect of CF on MOR compared to MOE agrees well with earlier studies [9, 11] and is related to the higher sensitivity of MOR to single structural defects. As expected, the reduction of the mechanical properties of structural timber is slightly lower than with small clear specimens [9]. Since a presence of CF only slightly affects the modulus of elasticity, CF will not reliably be detected by machine stress grading methods relying on the dynamic or (low stress level) static assessment of the modulus of elasticity, as reported already in earlier studies [9, $19,20]$. 
Table 9 Results of the multiple regression analysis for modulus of rupture (MOR, top) and modulus of elasticity (MOE, bottom) corresponding to model formulas 1 and 2 respectively

\begin{tabular}{|c|c|c|c|c|c|c|c|}
\hline \multicolumn{8}{|c|}{ Dependent variable: MOR } \\
\hline \multicolumn{2}{|l|}{ Source } & \multirow[t]{2}{*}{$\mathrm{DF}$} & Sum of squares & Mean square & $F$ value & \multicolumn{2}{|l|}{$\operatorname{Pr}>F$} \\
\hline \multicolumn{7}{|c|}{ Analysis of variance } & \\
\hline Model & & 7 & 30903 & 4414.74762 & 65.35 & 0001 & \\
\hline Error & & 555 & 37495 & 67.55924 & & & \\
\hline \multirow[t]{4}{*}{ Corrected total } & & 562 & 68399 & & & & \\
\hline & Root MSE & & 8.21944 & $R$-Square & 0.4518 & & \\
\hline & Dependent mean & & 50.46490 & Adj R-Sq & 0.4449 & & \\
\hline & Coeff var & & 16.28744 & & & & \\
\hline Variable & $\mathrm{DF}$ & Parameter estimate & Standard error & $t$ Value & $\operatorname{Pr}>|t|$ & $95 \%$ Confidence & Limits \\
\hline \multicolumn{8}{|c|}{ Parameter estimates } \\
\hline Intercept & 1 & -30.14410 & 10.83707 & -2.78 & 0.0056 & -51.43078 & -8.85741 \\
\hline DENS & 1 & 0.07233 & 0.01107 & 6.53 & $<.0001$ & 0.05057 & 0.09408 \\
\hline USMIN & 1 & 0.01025 & 0.00188 & 5.45 & $<.0001$ & 0.00656 & 0.01394 \\
\hline KMAX & 1 & -0.38636 & 0.03563 & -10.84 & $<.0001$ & -0.45635 & -0.31638 \\
\hline KCLU & 1 & -0.06284 & 0.01793 & -3.51 & 0.0005 & -0.09806 & -0.02763 \\
\hline $\mathrm{CW}$ & 1 & -0.05921 & 0.03350 & -1.77 & 0.0777 & -0.12502 & 0.00660 \\
\hline FUNG & 1 & -0.11295 & 0.03942 & -2.86 & 0.0043 & -0.19039 & -0.03551 \\
\hline CFIND & 1 & -8.07162 & 0.82103 & -9.83 & $<.0001$ & -9.68432 & -6.45892 \\
\hline \multicolumn{8}{|c|}{ Dependent variable: MOE } \\
\hline \multicolumn{2}{|l|}{ Source } & $\mathrm{DF}$ & Sum of squares & Mean square & $F$ Value & $\operatorname{Pr}>F$ & \\
\hline \multicolumn{8}{|c|}{ Analysis of variance } \\
\hline Model & & 7 & 1696245177 & 242320740 & 177.80 & $<.0001$ & \\
\hline Error & & 555 & 756402611 & 1362888 & & & \\
\hline \multirow[t]{4}{*}{ Corrected Total } & & 562 & 2452647788 & & & & \\
\hline & Root MSE & & 1167.42777 & $R$-Square & 0.6916 & & \\
\hline & Dependent mean & & 12362 & Adj R-Sq & 0.6877 & & \\
\hline & Coeff Var & & 9.44349 & & & & \\
\hline Variable & DF & Parameter estimate & Standard error & $t$ Value & $\operatorname{Pr}>|t|$ & 95\% Confidence & Limits \\
\hline \multicolumn{8}{|c|}{ Parameter estimates } \\
\hline Intercept & 1 & -24825 & 1539.21564 & -16.13 & $<.0001$ & -27848 & -21801 \\
\hline DENS & 1 & 26.34673 & 15.72989 & 16.75 & $<.0001$ & 23.25699 & 29.43647 \\
\hline USMIN & 1 & 4.47382 & 0.26700 & 16.76 & $<.0001$ & 3.94936 & 4.99828 \\
\hline KMAX & 1 & -48.24031 & 5.06052 & -9.53 & $<.0001$ & -58.18042 & -38.30021 \\
\hline KCLU & 1 & -7.40907 & 2.54625 & -2.91 & 0.0038 & -12.41054 & -2.40760 \\
\hline $\mathrm{CW}$ & 1 & -26.61012 & 4.75876 & -5.59 & $<.0001$ & -35.95750 & -17.26274 \\
\hline FUNG & 1 & -11.22058 & 5.59959 & -2.00 & 0.0456 & -22.21956 & -0.22159 \\
\hline CFIND & 1 & -525.60071 & 116.61251 & -4.51 & $<.0001$ & -754.65654 & -296.54489 \\
\hline
\end{tabular}

The calculation of the characteristic values for MOR, MOE and DENS is documented in Table 10. In this approach the sub-samples of beams without and with CF were combined, but stratified by strength classes. The calculated characteristic values all exceed the limits in the given strength classes C20 and C24. This result means that in spite of the general and statistically significant reduction of the mechanical properties, visually graded structural timber even with CF meets the requirements with an adequate safety margin. 
Table 10 Verification of characteristic values of strength classes according to prEN 384 [16]

\begin{tabular}{|c|c|c|c|c|c|c|c|c|c|c|c|}
\hline \multirow[b]{2}{*}{ Strength class ${ }^{\mathrm{a}}$} & \multicolumn{5}{|c|}{ Test results ${ }^{\mathrm{b}}$} & \multicolumn{3}{|c|}{ Adjustments to reference conditions ${ }^{c}$} & \multicolumn{3}{|c|}{ Characteristic values $^{\mathrm{d}}$} \\
\hline & $n$ & Mean & Std & Min & $5 \%-\mathrm{P}$ & $k_{M C}$ (factor) & $k_{h}$ (divis.) & adjusted values & $k_{s}$ (factor) & char. Value & limit \\
\hline & $\operatorname{MOR}\left[\mathrm{N} / \mathrm{mm}^{2}\right]$ & & & & & & & & & & \\
\hline $\mathrm{I}+\mathrm{II} / \mathrm{C} 24$ & 169 & 56.6 & 9.0 & 22.2 & 39.1 & - & 1.064 & 36.8 & 0.89 & 32.7 & 24 \\
\hline III/C20 & $\begin{array}{l}197 \\
\text { MOE }\left[\mathrm{N} / \mathrm{mm}^{2}\right]\end{array}$ & 48.7 & 10.6 & 12.2 & 30.1 & & & 28.2 & 0.90 & 25.5 & 20 \\
\hline $\mathrm{I}+\mathrm{II} / \mathrm{C} 24$ & 169 & 13464 & 1683 & 8608 & 10397 & 1.060 & - & 14272 & - & 14272 & 11000 \\
\hline III/C20 & $\begin{array}{l}197 \\
\text { Density }\left[\mathrm{kg} / \mathrm{m}^{3}\right]\end{array}$ & 12432 & 1839 & 7362 & 9279 & & & 13178 & & 13178 & 9500 \\
\hline $\mathrm{I}+\mathrm{II} / \mathrm{C} 24$ & 169 & 475 & 33 & 367 & 422 & 0.985 & - & $468 / 33$ & - & 414 & 350 \\
\hline III/C20 & 197 & 480 & 35 & 395 & 427 & & & $473 / 34$ & & 416 & 330 \\
\hline
\end{tabular}

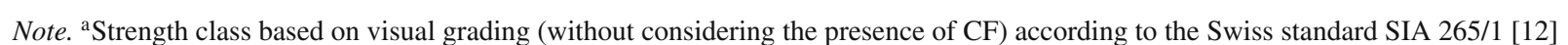

${ }^{\mathrm{b}}$ Abbreviations of sample statistics: $\mathrm{n}=$ sample size, Mean $=$ arithmetic mean, Std $=$ standard deviation, Min $=$ minimum value, $5 \%$-P $=$ empirical 5 th percentile.

The input values for the calculation of the characteristic values are printed in bold

${ }^{\mathrm{c}}$ Conversion to reference conditions according to prEN 384: $\mathrm{k}_{m c}$ : Correction factor wood moisture content $15 \rightarrow 12 \%$, $\mathrm{k}_{h}$ : Correction factor timber size / height of beam $(150 / 110)^{0.2}$, adjusted values: property values at reference conditions. No adjustments to a pure bending MOE were made, which leads to a more conservative estimation of the characteristic values of MOE. Also no adjustments were made for the density as determined from mass and volume of the whole beams

${ }^{\mathrm{d}}$ Verification of characteristic values: $\mathrm{k}_{S}$ : correction factor for sample size, char. value: characteristic value calculated from tested sample, limit: expected characteristic value according to SIA 265 [17] and EN 338 [14] for the given strength classes 
Moreover, during the usual visual grading process in a sawmill, some of the beams with CF would have been detected and probably discarded.

\subsection{Effect of the 'size' of CF}

Multiple regression analysis similar to the models presented under 3.2 failed to show evidence for an improvement of the model fit by the inclusion of the recorded $\mathrm{CF}$ 'intensity' variables $\mathrm{NCF}, \mathrm{CFMAX}$ and CFLEN instead of the binary indicator variable for the presence of CF (CFIND). This is interpreted as a general difficulty to describe the 'damaging' dimensions of CF. Although on average there is an increas-
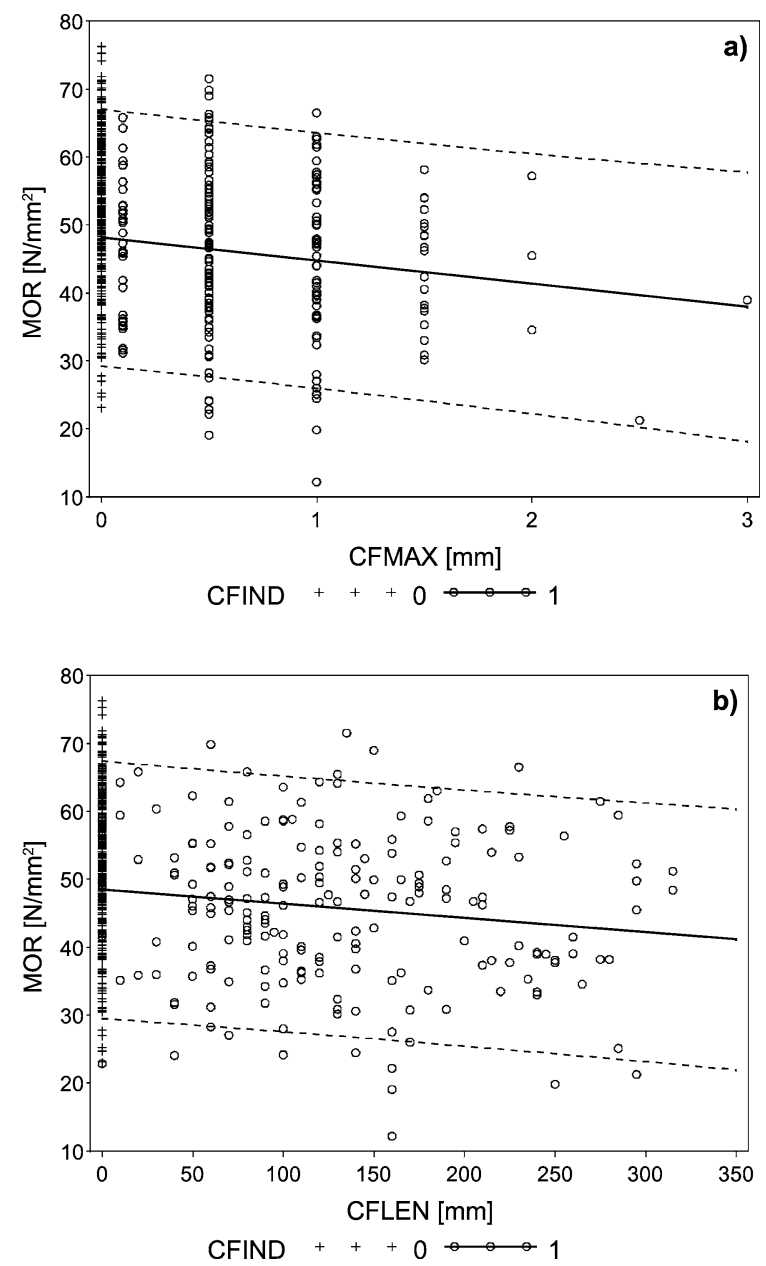

Fig. 5 Effect of the axial 'width' CFMAX (a) and the circumferential length CFLEN of the largest CF (b) on the modulus of rupture (MOR). The solid line indicates the linear regression line, the dotted lines enclose the $90 \%$ confidence band for individual predicted values for the beams with $\mathrm{CF}$ ing negative effect on MOR with an increasing number and 'size' of $\mathrm{CF}$, a strength prediction for single beams based on the macroscopic appearance of the $\mathrm{CF}$ would be unreliable due to the very high variability and hence wide confidence bands (Fig. 5). It is evident that the lowest observed MOR values do not necessarily correspond to particularly 'large' CF. The correlation between MOE and the 'size' variables of $\mathrm{CF}$ is even weaker.

Based on these findings, the use of allowable 'size' limits for CF in grading procedures seems neither safe nor practical. This result is in contrast to some earlier reports, where such limits have been proposed $[10,11]$.

\subsection{Fracture behaviour}

If $\mathrm{CF}$ were involved in the mode of failure, frequently abnormally brittle and short-fibred fractures have been observed (Fig. 1). Fracture occurred often suddenly and without any prior indications. In some cases the beams were broken completely over the whole cross-section. The low-strain failure mode is also apparent in the total deflection at maximum load (DMAX, Fig. 6). Average total deflection at maximum load was only $39 \mathrm{~mm}$ in beams with CF compared to $56 \mathrm{~mm}$ in beams without $\mathrm{CF}$, which corresponds to a reduction of $30 \%$ (Table 8). The beams with the lowest MOR all contained CF and exhibited very low deformations (Fig. 6).

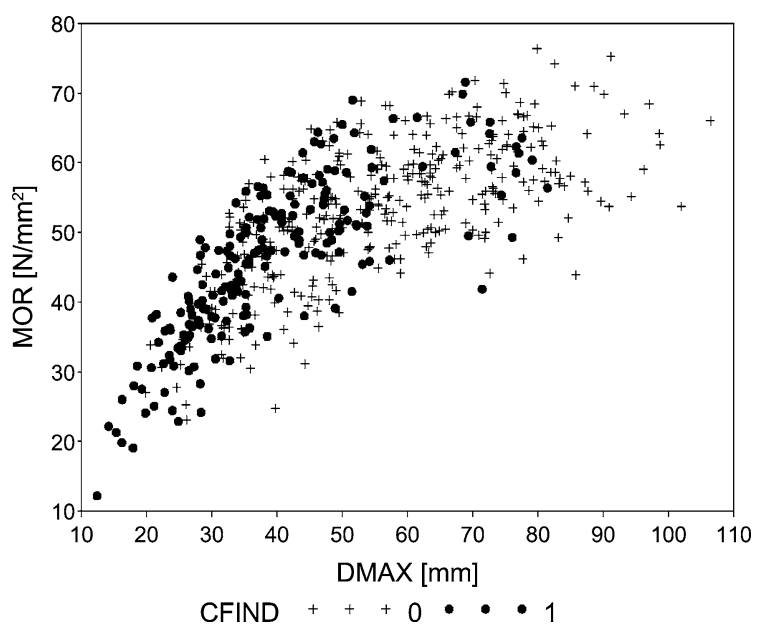

Fig. 6 Effect of the presence of CF (CFIND) on the total deformation at maximum load (DMAX), shown in relationship to the modulus of rupture (MOR) 
This brittle fracture behaviour has been observed already in earlier studies [1, 5, 11]. Moreover, CF have been reported to be particularly sensitive to impact loads (e.g. impact bending tests), which showed a high strength reduction by $\mathrm{CF}[5,9]$.

\section{Conclusions}

Based on this case study the following conclusions are drawn regarding the influence of wind-induced $\mathrm{CF}$ on the mechanical properties of spruce structural timber:

1. There is a statistically significant reduction of MOR and MOE in bending of squared timber beams containing CF compared to beams without visible CF. The effect is more pronounced regarding MOR than regarding MOE.

2. Despite the general reduction of strength and elasticity, the limits for the characteristic values in the strength classes C20 and C24 of visually graded structural timber (according to the Swiss standard SIA 265/1 [12]) are still exceeded. Considering the decreasing influence of other structural defects, this may however not be the case in higher strength grades.

3. Because the modulus of elasticity is only slightly affected by the presence of $\mathrm{CF}$, machine stress grading methods relying on the dynamic or (low stress level) static assessment of the modulus of elasticity are not able to reliably detect CF. Machine stress grading of timber containing $\mathrm{CF}$ without an additional visual inspection may therefore lead to an overestimation of expected MOR and wrong strength grades.

4. The macroscopically visible appearance ('size') of the CF is only a weak indicator for the potential reduction of MOR and MOE. This makes it impossible to distinguish between 'benign' and 'malignant' $\mathrm{CF}$ and to define allowable 'size' limits for $\mathrm{CF}$ for visual grading procedures. Thus only a strict exclusion of CF seems practical.

5. The failure behaviour of timber containing CF is frequently abnormally brittle and exhibits low-strain, short-fibred fractures.

6. Because of the potential safety risk and the difficult prediction of their strength reduction, detected CF should be excluded from load bearing structural elements stressed in tension or bending and explicitly addressed in the relevant grading standards (as in SIA 265/1 [12]). Timber containing CF should only be used in compression loaded or not load-critical applications.

Acknowledgements The presented work was funded partly by the Swiss Forest Agency within the framework of the 'Lothar Evaluations- und Grundlagenprojekte'. The assistance of D. Heer and $\mathrm{K}$. Weiss in logistics, grading and mechanical testing is gratefully acknowledged.

\section{References}

1. Trendelenburg R (1940) Über Faserstauchungen in Holz und ihre Überwallung durch den Baum. Holz als Roh- und Werkstoff 3(7/8):209-221

2. Mergen F, Winer HI (1952) Compression failures in the boles of living conifers. Journal of Forestry 50:677-679

3. Delorme A (1974) Über das Auftreten von Faserstauchungen in Fichtensturmholz. Forstarchiv 45(7):121-128

4. Timell TE (1986) Compression Wood in Gymnosperms. Volume 3, Chapter 15.2.1.5. Springer, Berlin

5. Koch G (1999) Sekundäre Veränderungen im Holz dynamisch beanspruchter Fichten (Picea abies [L.] Karst.) aus immissionsbelasteten und windexponierten Hochlagenbeständen. Mitteilungen der Bundesforschungsanstalt für Forst- und Holzwirtschaft, Hamburg, Nr. 192

6. Kucera LJ, Bariska M (1982) On the fracture morphology in wood. Part 1: A SEM-study of deformations in wood of spruce and aspen upon ultimate axial compression load. Wood Sci Technol 16:241-259

7. Wilkins AP (1986) The nomenclature of cell wall deformations, Wood Sci Technol 20:97-109

8. Terziev N, Geoffrey D, Marklund A (2005) Dislocations in Norway spruce fibres and their effect on properties of pulp and paper. Holzforschung 59:163-169

9. Sonderegger W, Niemz P (2004) The influence of compression failure on the bending, impact bending and tensile strength of spruce wood and the evaluation of non-destructive methods for early detection. Holz als Roh- und Werkstoff 62(5):335-342

10. Glos P, Denzler JK (2004) Einfluss von Faserstauchungen auf die Festigkeit von Fichtenbauholz. Schweiz Z Forstwes 155(12):528-532

11. Hoffmeyer P (2003) Mechanical Properties of Timber from Wind Damaged Norway Spruce. In: L. Salmén (Ed) Proceedings of the Second International Conference of the European Society for Wood Mechanics, Stockholm, Sweden, 25-28, May 2003

12. SIA 265/1 (2003) Construction en bois - Spécifications complémentaires. Société Suisse des Ingénieurs et des Architectes, Zurich

13. Arnold M (2003) Compression Failures in wind-damaged Spruce Trees. In: B. Ruck et al. (ed) Proceedings Interna- 
tional Conference Wind Effects on Trees. 16-18. September 2003, University of Karlsruhe, Germany, Karlsruhe, pp 253260

14. EN 338 (2003) Structural timber - Strength classes

15. EN 408 (1995) Timber structures - Structural timber and glued laminated timber - Determination of some physical and mechanical properties

16. prEN 384 (2000) Structural timber - Determination of characteristic values of mechanical properties

17. SIA 265 (2003) Construction en bois. Société Suisse des Ingénieurs et des Architectes, Zurich
18. Steiger R (1995) Biege - Zug- und Druckversuche an Schweizer Fichtenholz', Forschungsbericht ETH/IBK Nr. 207, Birkhäuser, Basel

19. Steiger R (1996) Mechanische Eigenschaften von Schweizer Fichten-Bauholz bei Biege-Zug-Druck-und kombinierter M/N-Beanspruchung; Sortierung von Rund-und Schnittholz mittels Ultraschall, Forschungsbericht ETH/IBK Nr. 221, Birkhäuser, Basel

20. Bernasconi A, Boström L, Schacht B (1999) Detection of severe timber defects by machine grading. Proceedings CIBW18, 32. meeting, Graz, Austria, paper 32-5-2 